\title{
Exploitation of New Microbial Resources for Bioactive Compounds and Discovery of New Actinomycetes
}

\author{
Yōko Takahashi* \\ Kitasato Institute for Life Sciences, Kitasato University, and The Kitasato Institute, \\ 5-9-1 Shirokane, Minato-ku, Tokyo 108-8641, Japan \\ (Received Nov. 9, 2004)
}

\section{INTRODUCTION}

One of the more efficient ways of discovering novel bioactive metabolites from microorganisms is through the isolation of new microorganisms. About $70 \%$ of novel bioactive metabolites have been derived from actinomycete strains.

Isolation of new actinomycete strains has been attempted using particular habitats and various techniques to screen for new bioactive compounds in our laboratory. Studies of the vertical distribution of actinomycetes in soil ${ }^{1)}$, isolation of actinomycetes from desert soils ${ }^{2)}$ or fallen leaves ${ }^{3)}$, selective isolation of Kitasatospora strains using novobiocin ${ }^{4)}$ or of Actinoplanes strains using chemotactic methods ${ }^{5)}$, and use of gellan gum as a solidifying agent ${ }^{6)}$ were performed. These attempts resulted in the discovery of two new genera of actinomycetes, $K$. setae KM-6054 ${ }^{\mathrm{T} 7}$, 8 ) and Longispora albida K97-0003 ${ }^{\mathrm{T} 6)}$, nine new species (K. cineracea $\mathrm{SK}-3255^{\mathrm{T} 4)}, K$. griseola AM-9660 ${ }^{\mathrm{T} 9)}$, K. niigatensis $\mathrm{SK}-3406^{\mathrm{T} 4)}$, K. phosalacinea KA-338 ${ }^{\mathrm{T} 9)}$, Amycolatopsis azurea AM-3696 ${ }^{\mathrm{T} 10,11)}$, Actinoplanes capillaceus $\mathrm{K} 95-5561^{\mathrm{T} 5)}$, Promicromonospora sukumoe SK-2049 ${ }^{\mathrm{T}} 2$, Streptomyces avermectinius (S. avelmitilis) MA-4680 ${ }^{\mathrm{T} 13)}$, S. scabrisporus KM$4927^{\mathrm{T} 14)}$ ) and two new subspecies (Micromonospora echinospora subsp. armeniaca KMR-593 ${ }^{\mathrm{T} 15)}$ and Saccharothrix aerocolonigenes subsp. staurosporeus AM$2282^{\mathrm{T} 16)}$ ) that produce novel active compounds.

Although researchers have utilized numerous approaches to isolate new microbes, the number of microorganisms that have been successfully and grown represents only a small portion of the total that exists. Hawksworth ${ }^{17)}$ and Whitman ${ }^{18)}$ reported that the number of known bacteria comprises no more than $10 \%$ of the estimated total number of species in the world. The isolation of unknown microbial strains thus represents an area of great potential. In the course of searching for factors facilitating bacterial colony growth, predominant bacterial strains were found to release into culture broths proteins that increase the number of bacterial colonies from soil samples. This protein was identified as superoxide dismutase (SOD) ${ }^{19)}$.

The present paper reviews taxonomical characteristics and submerged spore formation of genus Kitasatospora and taxonomical properties of Longispora albida, representing a new genus, isolated using gellan gum as a solidifying agent, and the effect of SOD produced by predominant bacterial strains on bacterial colony growth.

\section{GENUS KITASATOSPORA}

2-1. Discovery of the genus Kitasatospora and associated taxonomic criteria ${ }^{7,20}$ )

Genus Kitasatospora was proposed for $K$. setae KM$6054^{\mathrm{T}}$ as a new genus by Ōmura, Takahashi, Iwai \& Tanaka in 1982. In the course of screening for new bioactive metabolites, the actinomycete strain KM- $6054^{\mathrm{T}}$ was identified as a producer of a nematocidal substance, setamycin, which represented the first of the setamycin-bafilomycin group of antibiotic compounds ${ }^{21)}$. Figure 1 and Table 1 show the taxonomical characteristics of genus Kitasatospora. Kitasatospora strains produce long spore chains on aerial mycelia and contain both LL-diaminopimelic acis (DAP) and meso-DAP in the cell wall of cells obtained in submerged culture. Kitasatospora strains produce submerged spores in submerged culture. Aerial spores on solid culture and submerged spores in submerged culture contain LL-DAP, while mycelia in both cultures predominantly contain meso-DAP. These properties are unique to the genus. The genus Kitasatospora was transferred to the genus Streptomyces in hybridization experiments using a Streptomyces-specific 18bp oligonucleotide probe of $16 \mathrm{~S}$ rRNA gene as described in 1992 by Wellington et al. ${ }^{22)}$ In 1997, Zhang et al. ${ }^{23)}$ reported the revival of the taxonomic status of genus Kitasatospora on the basis of phylogenetic analysis using 16S rRNA genes and 16S-23S rRNA gene spacers. They concluded that genus Kitasatospora was distinct from Streptomyces as a legitimate genus on the basis of phenotypic and generic differences. Since the 1982 proposal of Kitasatospora ${ }^{7)}, 13$ species have been validly described. Figure 2 shows a phylogenetic tree based on 16S rRNA gene sequences of Kitasatospora and Streptomyces strains. Kitasatospora strains form a stable monophyletic clade separated from the Streptomyces cluster. Several strains have been reported as producers of novel bioactive compound with varying structures and interesting activities. We have proposed five of the Kitasatospora species, and some were isolated using agar medium containing novobiocin, an antibiotic that Kitasatospora strains are resistant to ${ }^{4}$. Two novel bioactive compounds were iso-

*Corresponding author. Phone: +81-3-5791-6133. Fax: +81-3-5791-6133. E-mail: ytakaha@lisci.kitasato-u.ac.jp 


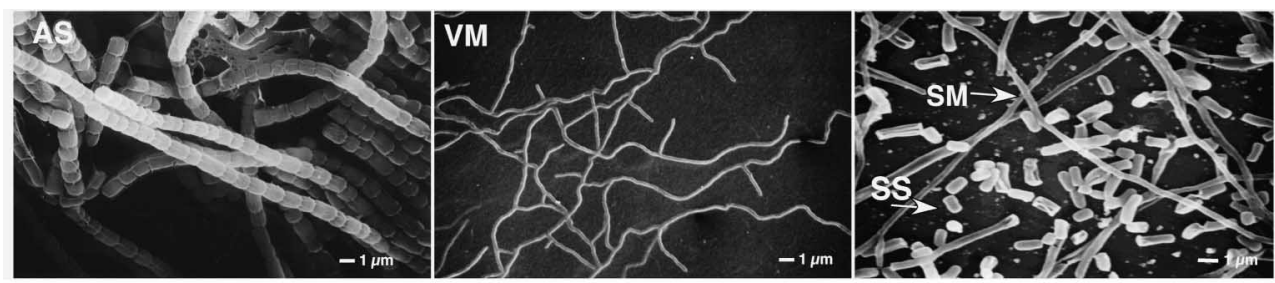

Fig. 1. Scanning electron micrographs of Kitasatospora setae KM-6054 ${ }^{\mathrm{T}}$. AS; Aerial spore, VM; Vegetative mycelium, SS; Submerged spore, SM; Submerged mycelium

Table 1. Taxonomic properties of genus Kitasatospora

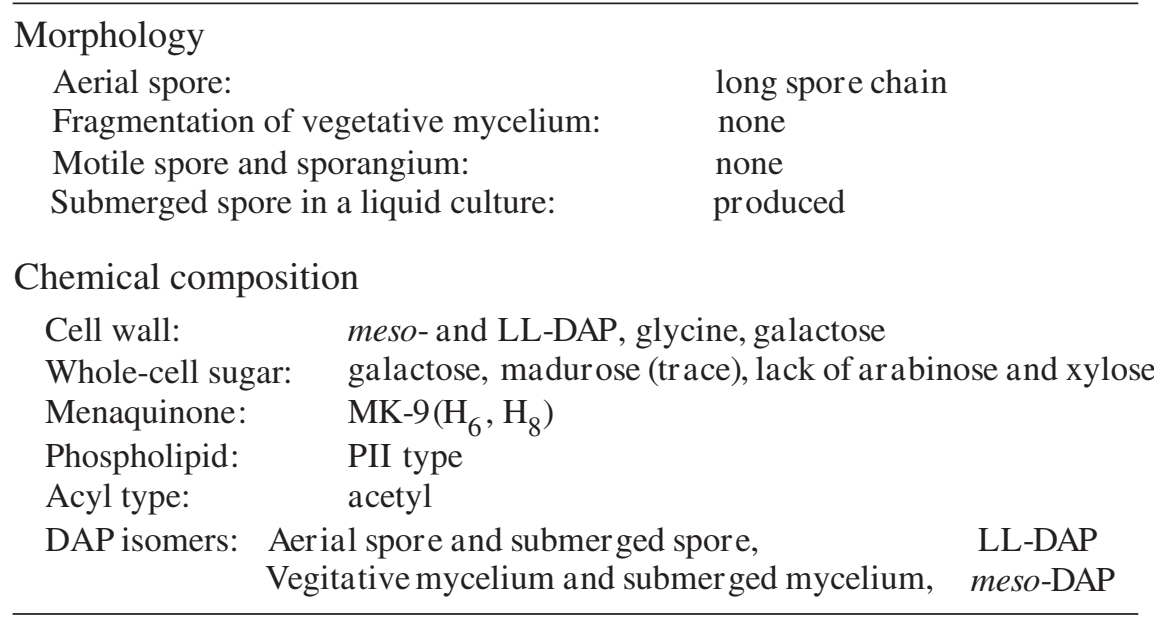

lated from cultured broths of $K$. setae $\mathrm{KM}-6054^{\mathrm{T}}$ and $K$. phosalacinea $\mathrm{KA}-338^{\mathrm{T}}$ : setamycin, possessing nematocidal activity; and phosalacine, possessing herbicidal activity, respectively.

\section{2-2. Relationship between cell morphology and chemi- cal composition ${ }^{24-26}$}

The most characteristic feature of the genus Kitasatospora is that both LL- and meso-DAP are contained in cells grown in submerged culture. A relationship between cell morphology and isomer content of DAP in submerged culture has been observed ${ }^{25)}$. Figure 3 shows time course for synchronous submerged culture. Only the resulting submerged spores were inoculated into liquid medium. After $1 \mathrm{~h}$, cells began to elongate, and subsequently developed gradually into mycelia. At 9 h, only mycelia were observed, with no submerged spores. However, submerged spores appeared again at $15 \mathrm{~h}$, and both submerged spores and mycelia were observed thereafter. Only LL-DAP was detected at the time submerged spores were inoculated. However, the relative amount of LL-DAP decreased rapidly, while meso-DAP content increased. LL-DAP content increased again after 11 $\mathrm{h}$, when submerged spores were actively produced. The increased meso-DAP content during 0-5 h and 19-24 h was closely related to synchronous elongation of mycelia from submerged spores. Almost equal amounts of LL-DAP and
meso-DAP were detected after $50 \mathrm{~h}$. DAP isomer types clearly corresponded to cell morphology. The relationship between morphology and DAP isomers represents a very important criteria in the chemotaxonomy of actinomycete strains, but had not previously been investigated until the examination of $K$. setae KM- $6054^{\mathrm{T}}$ by Takahshi et al. ${ }^{25)}$

Amino acid composition of the cell walls of aerial spores, submerged spores, vegetative mycelia and submerged mycelia were analyzed ${ }^{24,26)}$. Molar ratios of amino acids in both spores revealed similar Gly content (Table 2). The peptidoglycan structures were similar between the two kinds of spores, aerial and submerged, but differed from those of the two kinds of mycelia, vegetative and submerged.

\section{2-3. Mode of submerged spore formation}

Microautoradiographic analysis with incorporation of $\left[{ }^{3} \mathrm{H}\right]-\mathrm{GlcNac}$ in synchronous submerged cultures was performed to investigate where submerged spores are formed in the mycelia (data not shown). The $\left[{ }^{3} \mathrm{H}\right]-\mathrm{GlcNac}$ is actively incorporated into newly synthesized cell walls. Germinating spores were labeled at $4 \mathrm{~h}$, while the tips of hyphae were labeled at $9 \mathrm{~h}$, and short spore chains were then fragmented to yield submerged spores. Newly germinating spores were subsequently labeled. However, the old mycelia were not labeled and maintained forms without fragmentation. Old mycelia had already become inactive. Submerged spore for- 


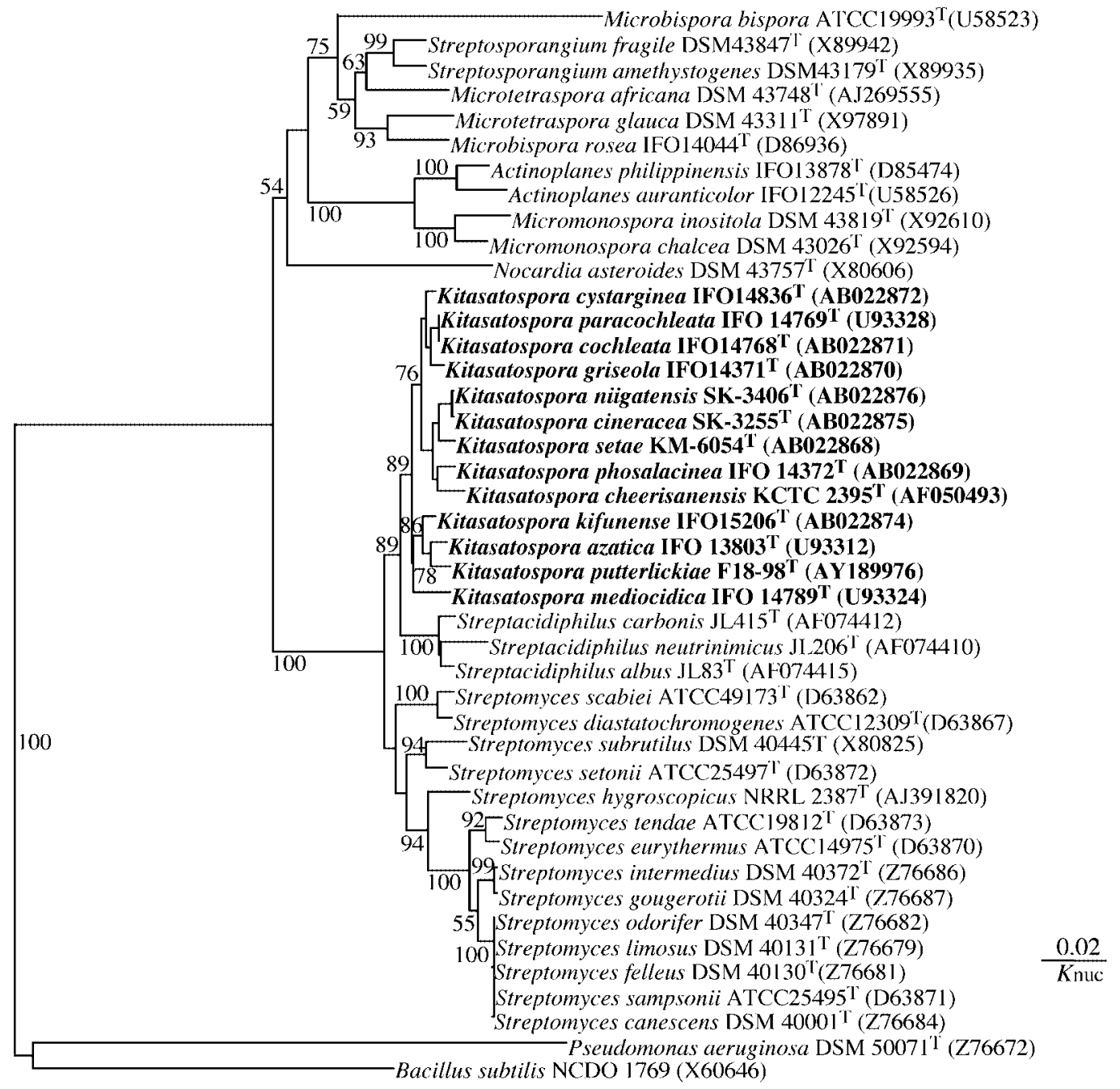

Fig. 2. Phylogenetic tree showing the position of Kitasatospora species based on 16S rRNA gene sequences.

Table 2. Amino acid composition of cell walls from four types of cells from Kitasatospora setae KM-6054 ${ }^{\mathrm{T}}$

\begin{tabular}{llccc}
\hline Cell & DAP-isomer & Ala & Glu & Gly \\
\hline Aerial spore & $1.0(\mathrm{LL})$ & 1.6 & 0.5 & 1.0 \\
Submerged spore & $1.0(\mathrm{LL})$ & 1.5 & 0.7 & 0.8 \\
Vegetative mycelium & $1.0($ meso $)$ & 1.6 & 0.7 & 0.2 \\
Submerged mycelium & 1.0 (meso) $^{*}$ & 1.6 & 0.7 & 0.4 \\
\hline
\end{tabular}

Values indicate molar ratio.

*A small amount of LL-DAP was also detected.

mation in $K$. setae KM-6054 $4^{\mathrm{T}}$ is illustrated in Figure 4. In Streptomyces griseus, submerged spore formation takes place in a late stage of cultivation, and submerged spores are abundantly produced by random fragmentation of mycelia. In Kitasatospora, submerged spores are formed in specific parts of the mycelia from an early stage, and mycelia co-exist with submerged spores until the late stage of culture. The tips and specific parts of mycelia are apparently committed to forming submerged spores ${ }^{27}$

Next, physiological regulation of the production of submerged spores was investigated in K. setae KM-6054 ${ }^{\mathrm{T}}$. Figure 5 shows experiments for feeding and shift-down. Submerged spores were not produced in a chemically defined minimal medium. In feeding experiments, the strain produced submerged spores when casamino acids were added within $4 \mathrm{~h}$ after inoculation, but not when added after $6 \mathrm{~h}$. In a shift-down experiments, the strain formed submerged spores when casamino acids were removed from minimal medium supplemented with casamino acids after $8 \mathrm{~h}$ of cultivation. Submerged spore formation may require incubation for at least $8 \mathrm{~h}$ under nutrient-rich conditions ${ }^{28)}$.

The above data strongly suggest that submerged spore formation in K. setae KM-6054 is not regulated by nutritional starvation, but by a kind of clock mechanism.

Correlations between metabolic and morphological differentiation, and the mechanisms of submerged spore formation are interesting subjects in Kitasatospora. 

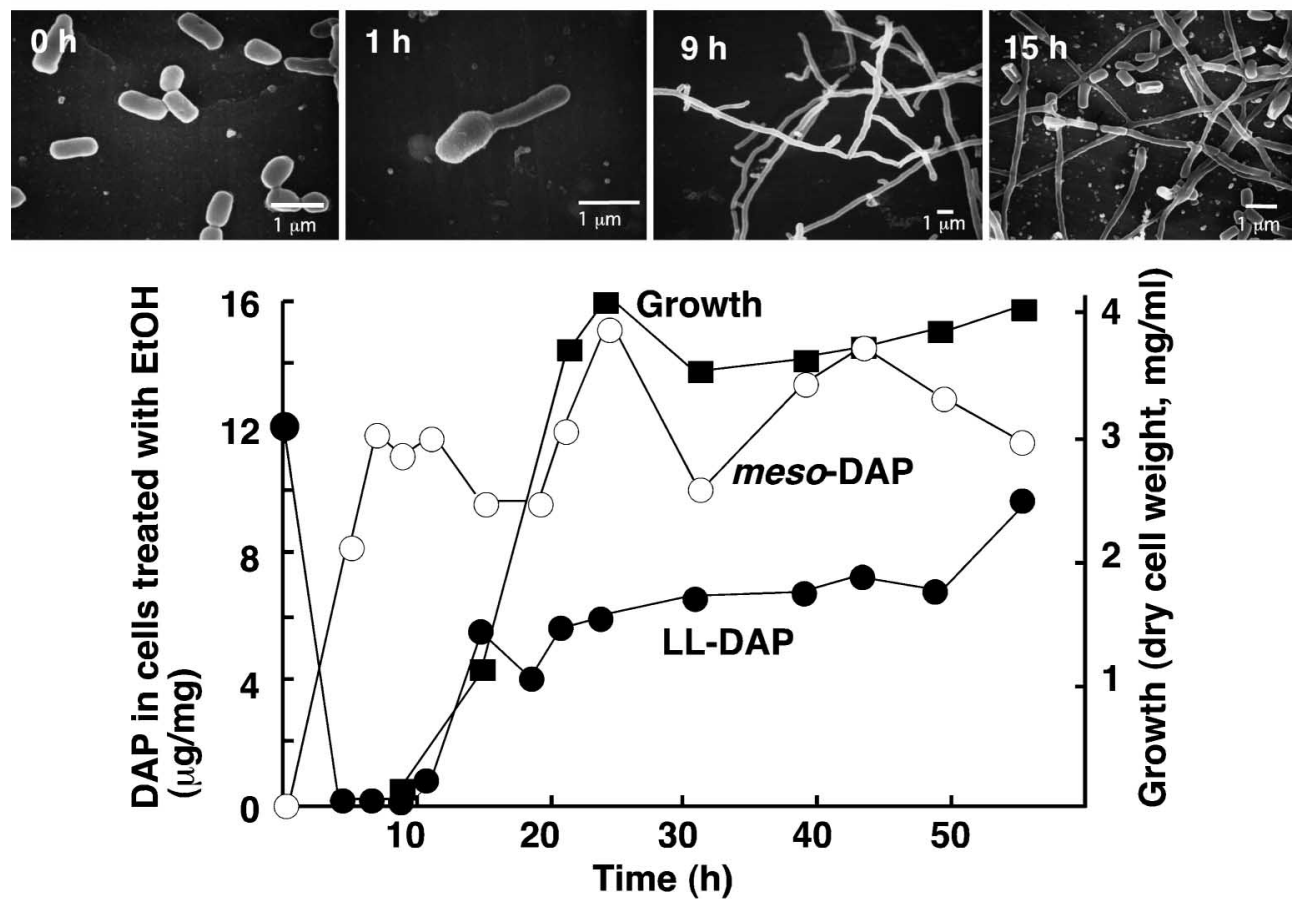

Fig. 3. Time course of LL-and meso- DAP contents in whole cells of Kitasatospora setae KM- 6054T grown in submerged culture.

(A)
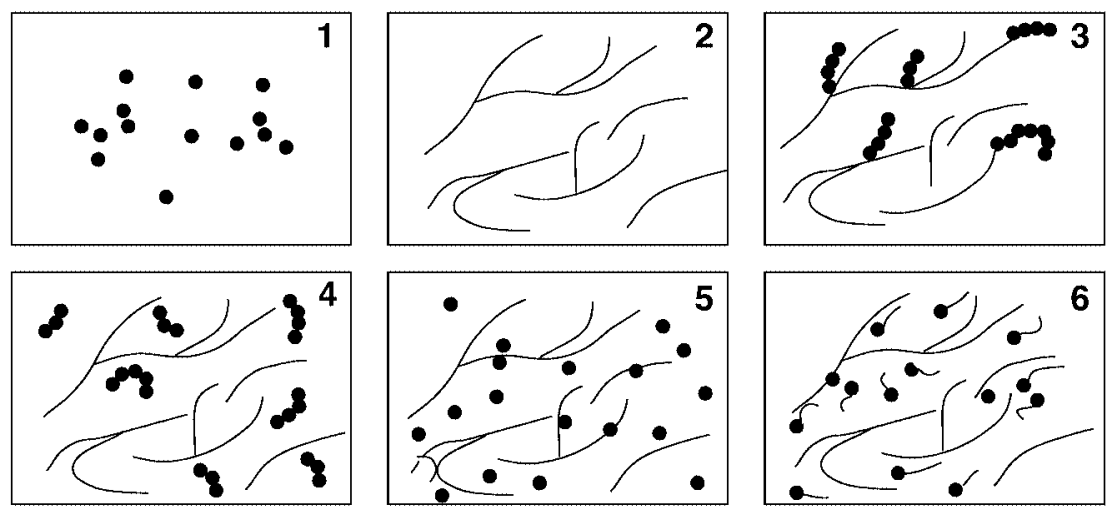

(B)
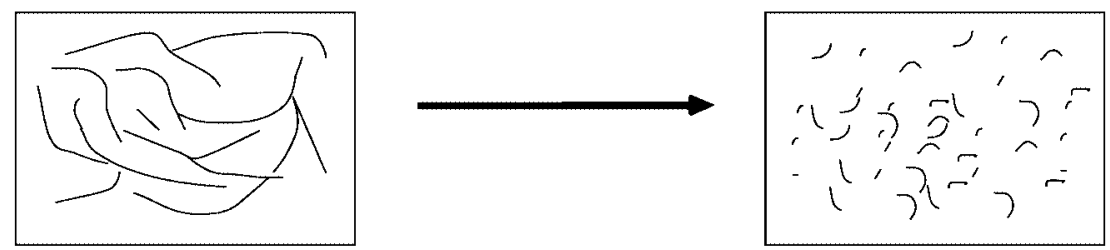

Fig. 4. Comparison of Kitasatospora setae KM-6054 ${ }^{\mathrm{T}}$ (A) with Streptomyces griseus (B) in submerged spore formation.

\section{USE OF GELLAN GUM AS A SOLIDIFYING AGENT FOR ISOLATION OF BACTERIAL STRAINS}

Suzuki et al..$^{29)}$ reported gellan gum as a useful solidifying agent for selective isolation of the genus Actinobacteria.
This method was applied with the intention of isolating rare actinomycete strains. Strain K97-0003 ${ }^{\mathrm{T}}$ was isolated and classified as representing a new genus, Longispora albida K97-0003 ${ }^{\mathrm{T} 6)}$. Furthermore, actinohibin, a novel anti-HIV protein, was found in culture broth of the $\operatorname{strain}^{30)}$. Strain K97-0003 ${ }^{\mathrm{T}}$ grew on various agar media, but did not produce 


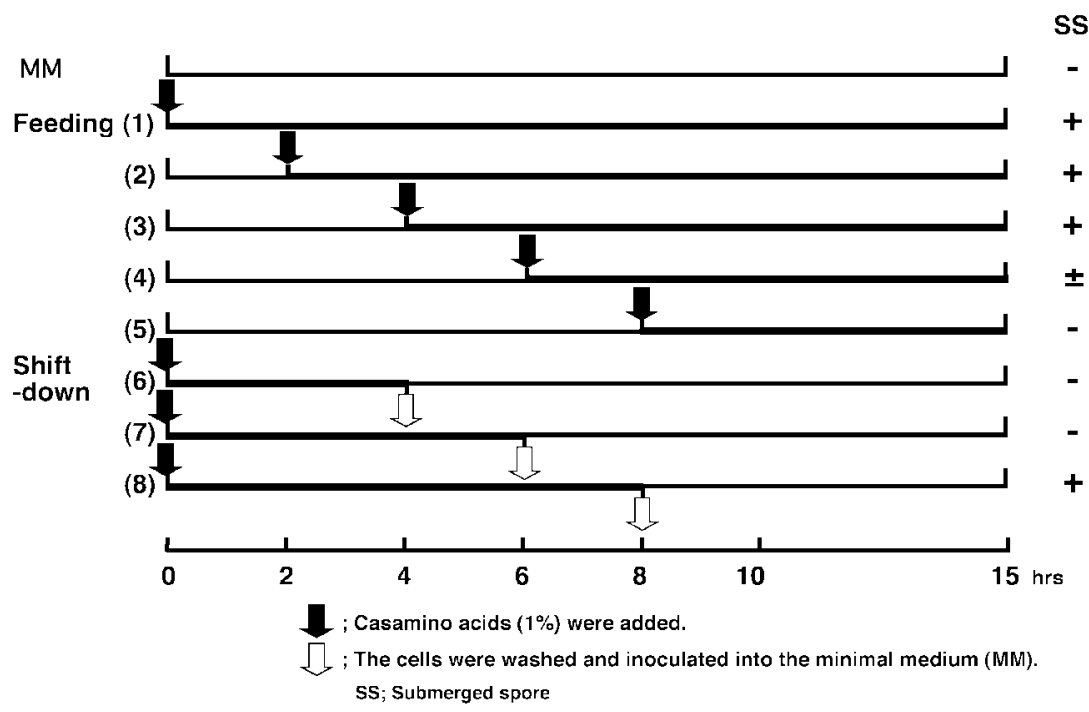

Fig. 5. Effect of nutrients on submerged spore formation (SS) in Kitasatospora setae KM-6054 ${ }^{\mathrm{T}}$.
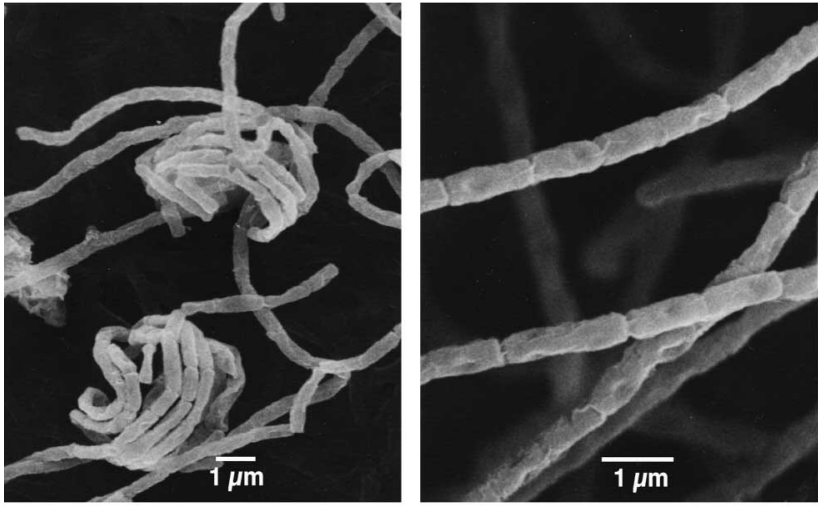

Fig. 6. Scanning electron micrographs of aerial spore chains of Longispora albida $\mathrm{K} 97-0003^{\mathrm{T}}$ grown on $1 \%$ Gellan gum-water proline medium.

aerial mycelia. When gellan gum was substituted for agar as a solidifying agent, aerial mycelia grew slightly on a limited number of media and spores were produced on 1/10 V8 gellan gum containing $\mathrm{CaCl}_{2}$. Taxonomical characteristics are shown in Figure 6 and Table 3. Strain K97-0003 ${ }^{\mathrm{T}}$ was regarded as representing a new genus on the basis of morphological and chemotaxonomic properties, in addition to phylogenetic analysis based on 16S rDNA sequence data.

\section{EFFECT OF SUPEROXIDE DISMUTASE PRO- DUCED BY PREDOMINANT BACTERIAL STRAINS ON ISOLATION OF MICROORGANISMS FROM SOIL SAMPLES}

The scope of microbial resources should be expanded to include unknown bacterial strains in order to accelerate the discovery of new bioactive compounds. Predominant strains in the soil may exert influences on the growth of other bacterial colonies, so 7 strains (strains $A \sim G$ ) that predominantly appeared on agar plates were isolated. The colony-enhancing activity of culture filtrates from these strains was investigated using glucose-peptone-meat extract (GPM) agar medium. Figure 7 shows the number of colonies from a soil sample on GPM agar medium. Culture filtrates from strains $\mathrm{C}$ and $\mathrm{G}$ increased the number of bacterial colonies compared to those with no addition and other strains. A common 24$\mathrm{kDa}$ growth-promoting protein was detected in the two culture broths and identified as microbial SOD, an enzyme that converts superoxide $\left(\mathrm{O}_{2}^{-}\right)$to $\mathrm{O}_{2}$ and hydrogen peroxide $\left(\mathrm{H}_{2} \mathrm{O}_{2}\right)$. N-Terminal amino acid sequences of proteins from culture filtrates of strains $C$ and $G$ were STFQLPKLSYDYDELEPYIDSNT or SEFQLPKLSYDYDELEPHIDSNT, respectively. Commercially available SOD also enhanced the appearance of soil bacteria colonies. Addition of catalase, which scavenges $\mathrm{H}_{2} \mathrm{O}_{2}$, to SOD-supplemented agar medium further enhanced bacterial colony growth. About $3.7 \mathrm{nmol} / \mathrm{ml} / \mathrm{h}$ of $\mathrm{O}_{2}^{-}$was generated in the GPM agar medi$\mathrm{um}^{19)}$. These results demonstrate that $\mathrm{O}_{2}^{-}$generated in agarbased isolation medium reduces bacterial survival, and that this effect may be counteracted by the addition of SOD or SOD plus catalase.

Hoffman et al. reported that the number of colonies of Campylobacter fetus subsp. jejuni was increased by the addition of SOD at various oxygen levels ${ }^{31}$. Bogosian et al. reported that cells of Viblio vulnificus dropped into $\mathrm{H}_{2} \mathrm{O}_{2}$ sensitive under long-term starvation at $5^{\circ} \mathrm{C}$ recovered on agar medium containing catalase ${ }^{32}$. Our results strongly suggest that some of the bacterial cells are recovered by suppressing oxidative stress on the agar-based medium.

Numerous bacterial strains have been isolated using the above methods, and have some of them should be considered members of the new taxa of Actinobacteria. Phylogenetic 
Table 3. Taxonomic properties of genus Longispora.

\begin{tabular}{ll}
\hline $\begin{array}{l}\text { Morphology } \\
\text { Aerial spore; } \\
\text { Motile spore and sporangium; }\end{array}$ & $\begin{array}{l}\text { long spore chain } \\
\text { none }\end{array}$ \\
Chemical composition & \\
Cell wall amino acid; & $\begin{array}{l}\text { meso-DAP, glycine, alanine } \\
\text { glycolyl }\end{array}$ \\
Acyl type of peptidoglycan ; & $\begin{array}{l}\text { arabinose, galactose, xylose } \\
\text { Whole-cell sugar; }\end{array}$ \\
Diagnostic phospholipid ; & MK-10 $\left(\mathrm{H}_{4,6,8}\right)$ \\
Menaquinone ; &
\end{tabular}

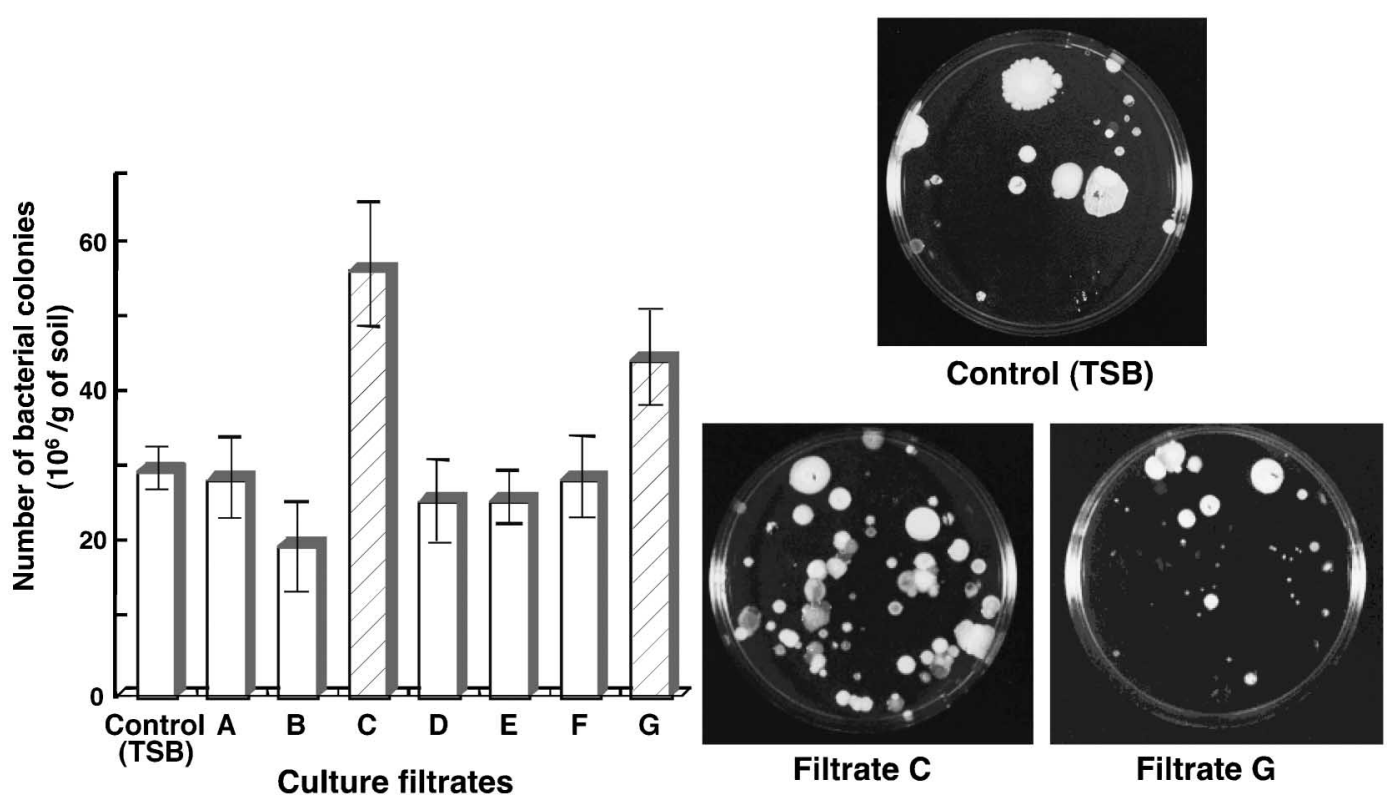

Fig. 7. Bacterial colonies grown on glucose-peptone-meat extract agar plates supplemented with culture filtrates of predominant strains (strains A G). Photographs show colonies on GPM agar medium supplemented with culture filtrates of strains C and G.

analysis based on 16S rRNA gene sequences revealed that the new isolates bear a close resemblance to some of uncultured clone sequences from data base (in preparation). Development of our simple method for enhancing the growth of bacterial colonies may enable the isolation of bacteria that would be missed using a general agar isolation medium.

Considerable differences exist between the environments in which microorganisms actually live and those available from man-made media. Most bacteria seem unable cannot grow on agar because they cannot compensate for gaps between the natural ecosystem and conditions in the artificial media. Our approaches using culture filtrates of predominant strains to obtain new microorganisms may contribute to new isolation methods.

\section{CONCLUSIONS}

Isolation of new actinomycete strains was attempted using various approaches, including particular habitats and unusual isolation methods ${ }^{33)}$. This allowed identification of numerous strains belonging to new taxa and the discovery of novel bioactive compounds possessing intriguing activities from the culture broths of these strains ${ }^{34}$.

To improve the chances of discovering new and useful bioactive compounds from microorganisms, the scope of microbial resources should be expanded to include bacterial strains other than actinomycetes, which have been recognized as the most promising resource of microbial products. We focused on Actinobacteria ${ }^{35)}$ strains other than filamen- 
tous actinomycetes as a new potential microbial resource, as these microorganisms have not yet been widely investigated. For this purpose, simple PCR methods were established to select Actibnobacteria strains from new isolates ${ }^{36)}$. This has resulted in the isolation of new anti-microbacterial compounds from the culture broth of strain K01- B 0171, belonging to genus Rodococcus (in preparation).

Newman et al. reported that although combinatorial techniques have proven successful as methods of optimizing structures, natural products remain useful as sources of novel structures $^{37)}$. Diversity of microorganisms seems likely to lead to diversity of secondary metabolites; that is, new microorganisms bring with them new and potentially beneficial substances.

\section{ACKNOWLEDGMENTS}

It is my great honor to have received the Award (2004) of the Society of Actinomycetes Japan (SAJ) and to have had the opportunity to deliver the Award lecture at the 2004 Annual Meeting of SAJ, on July 1st, 2004, on Awaji Island, Japan. I wish to express my gratitude to those who recommended me, the nominating committee and the board members of the SAJ. I am grateful to Dr. Masa Hamada, Dr. Kazuo Komagata and my many teachers among the SAJ members for their encouragement.

This work remains indebted to Prof. Satoshi Ōmura (The Kitasato Institute and Kitasato University) for inspiring me throughout my research career with his insightful guidance and advice. I wish to express my sincere thanks to Dr. Yuzuru Iwai, Dr. Akio Seino and Ms. Atsuko Matsumoto (The Kitasato Institute) for kind help, advice and encouragement on innumerable occasions. In addition, I am very grateful to all the members of Prof. Omura's research group at The Kitasato Institute and Kitasato University. This work would have never have been accomplished without the cooperation of my co-researchers and students. This present study was supported in part by a grant from the 21st Century COE Program of the Ministry of Education, Culture, Sports, Science and Technology (MEXT) in Japan and grants-in-aid for Scientific Research (C) from JSPS.

\section{REFERENCES}

1) Takahashi, Y.; Y. Seki, Y. Tanaka, R, Ōiwa, Y. Iwai \& S. Ömura: Vertical distribution of microorganisms in soil. Actinomycetologica 4: 1-6, 1990

2) Takahashi, Y.; A. Matsumoto, A. Seino, Y. Iwai \& S. Ōmura: Rare actinomycetes isolated from desert soils. Actinomycetologica 10: 91-97, 1990

3) Matsumoto, A.; Y. Takahashi, M. Mochizuki, A. Seino, Y. Iwai \& S. Ōmura: Characterization of actinomycetes isolated from fallen leaves. Actinomycetologica 12: 46-48, 1998

4) Tajima, K.; Y. Takahashi, A. Seino, Y. Iwai \& S. Ōmura: Description of two novel species of the genus Kitasatospora Ōmura et al. 1982, Kitasatospora cineracea sp. nov. and Kitasatospora niigatensis sp. nov. Int. J. Syst. Evol. Microbiol.
51: 1765-1771, 2001

5) Matsumoto, A.; Y. Takahashi, T. Kudo, Y. Iwai \& S. Ōmura: Actinoplanes capillaceus sp. nov., a new species of the genus Actinoplanes. Antonie van Leeuwenhoek 78: 107-115, 2000

6) Matsumoto, A.; Y. Takahashi, M. Shinose, A. Seino, Y. Iwai \& S. Ōmura: Longispora albida gen. nov., a new genus in the family Micromonosporaceae. Int. J. Syst. Evol. Microbiol. 53: 1553-1559, 2003

7) Ōmura, S.; Y. Takahashi, Y. Iwai \& H. Tanaka: Kitasatosporia, a new genus of the order Actinomycetales. J. Antibiot. 35: 1013-1019, 1982

8) Ōmura, S.; Y. Takahashi, Y. Iwa \& H. Tanaka: Revised nomenclature of Kitasatosporia setalba. Int. J. Syst. Bacteriol. 35: 221, 1985

9) Takahashi, Y.; Y. Iwai \& S. Ōmura: Two new species of the genus Kitasatosporia, Kitasatosporia phosalacinea sp. nov. and Kitasatosporia griseola sp. nov. J. Gen. Appl. Microbiol. 30: 377-387, 1984

10) Ōmura, S.; H. Tanaka, Y. Tanaka, Spiri-Nakagawa, P., R. Ōiwa, Y. Takahashi. K. Matsuyama \& Y. Iwai: Studies on bacterial cell wall inhibitors. VII. Azureomycins A and B, new antibiotics produced by Pseudonocardia azurea nov. sp. Taxonomy of the producing organisms, isolation, characterization and biological properties. J. Antibiot. 32: 985-994, 1979

11) Hensen, A.; H. W. Kothe \& R. M. Kroppenstedt: Transfer of Pseudonocardia azurea and "Pseudonocardia fastidiosa" to the genus Amycolatopsis, with emended species description. Int. J. Syst. Bacteriol. 37: 292-295, 1987

12) Takahashi, Y.; Y. Tanaka, Y. Iwai \& S. Ōmura. Promicromonospora sukumoe sp. nov. a new species of the Actinimycetales. J. Gen. Appl. Microbiol. 33: 509-519, 1987

13) Takahashi, Y.; A. Matsumoto, A. Seino, J. Ueno, Y. Iwai \& S. Ōmura: Streptomyces avermectinius sp. nov., an avermectin producing strain. Int. J. Syst. Evol. Microbiol. 52: 2163-2168. 2002

14) Xu, P.; Y. Takahashi, A. Seino, Y. Iwai \& S. Ōmura: Streptomyces scabrisporus sp. nov. Int. J. Syst. Evol. Microbiol. 54: 577-581, 2004

15) Takahashi, Y.; Y. I. Iwai \& S. Ōmura: Clostomicins, new antibiotics produced by Micromonospora echinospora subsp. armeniaca subsp. nov. Taxonomic study of the producing microorganism. J. Antibiot. 39: 1413-1418, 1986

16) Takahashi, Y.; M. Shinose, A. Seino, Y. Iwai \& S. Ōmura: Transfer of staurosporine-producing strain Streptomyces staurosporeus AM-2282 to the genus Saccharothrix as, Saccharothrix aerocolonigenes (labeda 1986) subsp. staurosporeus subsp. nov. Actinomycetologica 9: 19-26, 1995

17) Hawksworth, D. L.: The fungal dimension of biodiversity: Magnitude, significance, and conservation. Micol. Res. 95: 641-655, 1991

18) Whitman, W. B.; D. C. Colman \& W. J. Wiebe: Prokaryotes: The unseen majority. Proc. Natl. Acad. Sci. USA 95: 65786583, 1998

19) Takahashi, Y.; S. Katoh, N. Shikura, H. Tomoda \& S. Ōmura: Superoxide dismutase produced by soil bacteria increases bacterial colony growth from soil samples. J. Gen. Appl. Microbiol. 49: 263-266, 2003

20) Takahashi, Y.; A. Seino, Y. Iwai \& S. Ōmura: Taxonomic study and morphological differentiation of an actinomycete genus, Kitasatospora. Zent bl Bakteriol. 289; 265-284, 1999 
21) Ōmura, S.; K. Otoguro, T. Nishikiori, R. Ōiwa, and Y. Iwai: Setamycin, a new antibiotic. J. Antibiot. 34: 1253-1256, 1981

22) Wellington, E. M. H.; E. Stackebrandt, D. Sanders, J. Wolstrup, \& N. O. G. Jorgensen: Taxonomic status of Kitasatosporia, and proposed unification with Streptomyces on the basis of phenotypic and 16S rRNA analysis and emendation of Streptomyces Waksman and Henrici 1943, 339AL. Int. J. Syst. Bacteriol. 42: 156-160, 1992

23) Zhang, Z.; Y. Wang \& J. Ruan: A proposal to revive the genus Kitasatospora. Int. J. Syst. Bacteriol. 47: 1048-1054, 1997

24) Ōmura, S.; Y. Iwai, Y. Takahashi, K. Kojima, K. Otoguro \& R. Ōiwa: Type of diaminopimelic acid different in aerial and vegetative mycelia of setamycin-producing actinomycete KM- 6054. J. Antibiot., 34: 1633-1634, 1981

25) Takahashi, Y.; Y. Iwai \& S. Ōmura: Relationship between cell morphology and the types of diaminopimelic acid in Kitasatosporia setalba. J. Gen. Appl. Microbiol. 29: 459-465, 1983

26) Takahashi, Y.; T. Kuwana, Y. Iwai \& S. Ōmura: Some characteristics of aerial and submerged spores of Kitasatosporia setalba. J. Gen. Appl. Microbiol. 30: 223-229, 1984

27) Takahashi, Y.; Y. Iwai \& S. Ōmura: Mode of submerged spore formation in Kitasatosporia seta. J. Gen. Appl. Microbiol. 37 : 261-266, 1991

28) Takahashi, Y.; Y. Iwai \& S. Ōmura: Physiological regulation of sporulation of Kitasatosporia setae in submerged culture. Actinomycetologica 10: 43-49, 1996

29) Suzuki, S.; K. Takahashi, T. Okuda \& S. Komatsubara: Selective isolation of Actinobispora on gellan gum plate. Can. J. Microbiol. 44: 1-5,1998

30) Chiba, H.; J. Inokoshi, M. Okamoto, S. Asanuma, K. Matsuzaki, M. Iwama, K. Mizumoto, H. Tanaka, M. Oheda,
K. Fujita, H. Nakashima, M. Shinoses, Y. Takahashi \& S. Ōmura: Actinohivin, a novel anti-HIV protein from an actinomycete that inhibits syncytium formation: Isolation, characterization, and biological activities. Biochem. Biophys. Res. Commun. 282: 595-601, 2001

31) Hoffman, P. S.; H. A. George, N. R. Krieg \& R.M. Smibert: Studies of the microaerophilic nature of Campylobacter fetus subsp. jejuni. II. Role of exogenous superoxide anions and hydrogen peroxide. Can. J. Microbiol. 25: 8-16, 1979

32) Bogosian, G.; N. D.Aardema, E. V. Bourneuf, P. J. L. Morris \& J. P. O'Neil: Recovery of hydrogen peroxide-sensitive culturable cells of Vibrio vulnificus gives the appearance of resuscitation from Viable but nonculturable state. J. Bacteriol. 182: 5070-5075, 2000

33) Iwai, Y \& Y. Takahashi: Selection of microbial sources of bioactive compounds. In The search for bioactive compounds from microorganisms, ed. by Ōmura, S., Spring-Verlag New York, Inc., New York, pp. 281-302,1992

34) Takahashi,Y.\& S. Ōmura: Isolation of new actinomycetes for the screening of new bioactive compounds. J. Gen. Appl. Microbiol. 49: 141-154, 2003

35) Stackebrandt, E.; F. A. Rainey \& N. L. Ward-Rainey: Proposal for a new hierarchic classification system, Actinobacteria classis nov. Int. J. Syst. Bacteriol. 47: 479-491, 1997

36) Yu, L-Y.; Y. Takahashi, A. Matsumoto, A. Seino, Y. Iwai \& S. Ōmura: Application of PCR for distinguishing Gram-positive bacteria with high DNA G+C content from new isolates. Actinomycetologica 16: 1-5, 2002

37) Newman, D. J.; G. M. Cragg \& K. M. Snader: Natural products as sources of new drugs over the period 1981-2002. J. Nat. Prod. 66: 1022-1037, 2003 